
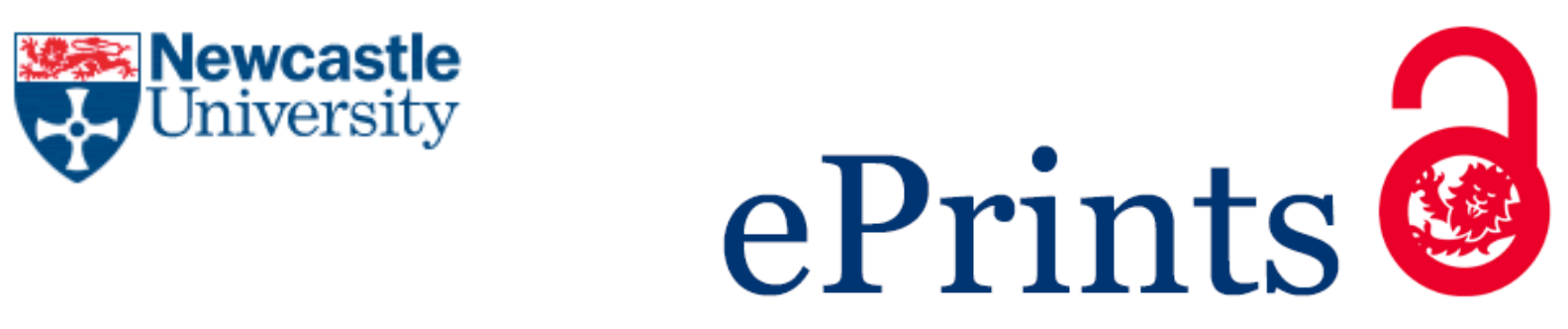

Roe MH, Sarlöv Herlin I, Speak SE.

Identity, food and landscape character in the urban context.

Landscape Research 2016, 41(7), 757-772.

\title{
Copyright:
}

This is an Accepted Manuscript of an article published by Taylor \& Francis in Landscape Research on 19/08/2016, available online: http://dx.doi.org/10.1080/01426397.2016.1212324

Date deposited:

$29 / 09 / 2016$

Embargo release date:

19 February 2018

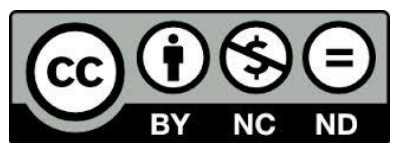

This work is licensed under a

Creative Commons Attribution-NonCommercial-NoDerivatives 4.0 International licence 


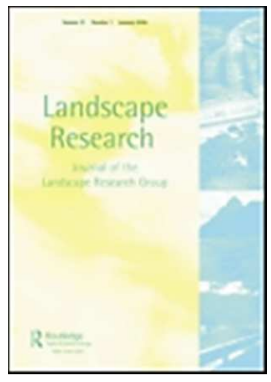

\section{Identity, Food and Landscape Character in the Urban Context}

\begin{tabular}{|c|l|}
\hline Journal: & Landscape Research \\
\hline Manuscript ID & CLAR-2015-0124.R2 \\
\hline Manuscript Type: & Special Issue Paper \\
\hline Keywords: & $\begin{array}{l}\text { FOOD LANDSCAPES, URBAN AGRICULTURE, FOODSCAPE, URBAN } \\
\text { CHARACTER, FOOD CONSUMPTION }\end{array}$ \\
\hline Abstract: & $\begin{array}{l}\text { Urban landscape character has been influenced by the evolving interactions } \\
\text { between people and their lifestyles, food and city form. Concerns of urban } \\
\text { populations about food production and consumption issues have led to a } \\
\text { greater awareness of our links with food and how our food choices } \\
\text { influence lifestyles. Consumer literature commonly categorises consumer } \\
\text { types or identities, while the landscape literature similarly categorises } \\
\text { landscapes through the production of typologies and character areas. In an } \\
\text { examination of concept, this paper identifies and examines urban } \\
\text { 'foodscape' character typologies where the interaction between people and } \\
\text { food has a strong influence on the form, function and character of the } \\
\text { present landscape. It draws on literature across a range of disciplines and } \\
\text { uses an examination of the city of Newcastle upon Tyne, UK to suggest a } \\
\text { typology which reveals seven foodscape character types which are } \\
\text { described and discussed. }\end{array}$ \\
\hline
\end{tabular}

\section{SCHOLARONE \\ Manuscripts}




\title{
Page 1 of 35

IDENTITY, FOOD AND LANDSCAPE CHARACTER IN THE URBAN CONTEXT

\author{
Maggie Roe \\ Senior Lecturer \\ School of Architecture, Planning \& Landscape \\ Newcastle University \\ Newcastle upon Tyne, NE1 7RU, UK \\ m.h.roe@ncl.ac.uk \\ $+441912228722$ \\ Ingrid Sarlöv Herlin \\ Professor of Landscape Planning \\ Department of Landscape Architecture \\ Swedish University of Agricultural Sciences \\ PO Box 58
}

ALNARP, SE 230 53, SE

ingrid.sarlov-herlin@sslu.se

$0046(0) 40415407$

Dr. Suzanne Speak

Senior Lecturer

School of Architecture, Planning \& Landscape

Newcastle University,

Newcastle upon Tyne, NE1 7RU, UK

s.e.speak@ncl.ac.uk

$+441912226000$

\begin{abstract}
Urban landscape character has been influenced by the evolving interactions between people and their lifestyles, food and city form. Concerns of urban populations about food production and consumption issues have led to a greater awareness
\end{abstract}


of our links with food and how our food choices influence lifestyles. Consumer literature commonly categorises consumer types or identities, while the landscape literature similarly categorises landscapes through the production of typologies and character areas. In an examination of concept, this paper identifies and examines urban 'foodscape' character typologies where the interaction between people and food has a strong influence on the form, function and character of the present landscape. It draws on literature across a range of disciplines and uses an examination of the city of Newcastle upon Tyne, UK to suggest a typology which reveals seven foodscape character types which are described and discussed.

Keywords: Food landscapes, urban agriculture, foodscape, urban character, food consumption

\section{INTRODUCTION}

This paper reports research that aims to examine the potential of a conceptual framework of urban 'foodscape' typologies for the examination of urban landscape character. It is based on an understanding of the importance of people's interaction with and experience of food and how that interaction moulds the character of cities. The concept is that people's food identities co-evolve with, and imprint on, the urban landscape character in various ways leading to the possibility of the identification of foodscape character types. This paper draws on an analysis of literature across a range of disciplines which defines 'foodscapes' in a variety of ways; the research develops a landscape framing of the idea of foodscapes. We use an adapted landscape character assessment and observational analysis from the city of Newcastle upon Tyne, in the UK, to support the development of the typology with the understanding that case study areas in different cultural contexts city locations and countries would reveal alternative, additional or just different types. Relevant literature analysed is used in the discussion concerning individual foodscape character types identified as well as providing the overall context for understanding the conceptual basis for the study.

\section{FOODSCAPES AND FOOD IDENTITIES IN THE CITY}

Socioeconomic, cultural and technological changes in the past century have brought about enormous changes in our relationship with and perceptions of food. There is a vast and growing literature in many different disciplines related to food. The term 'foodscape' is used particularly in geography (e.g. Goodman et al., 2010), urban agriculture (e.g. Solomon, 2012), planning and urban studies, social science and public 
health (e.g. Burgoine et al., 2009; Lake et al., 2010, 2012; Mikkelsen, 2011) where the term generally refers to food environments and the geographies of food, often in relation to the policy, identification and location of food outlets, and increasingly to alternative production and behaviour concerning food. It is also now being used in artistic applications to explore ethnographies, senses, meanings and materialities (Roe \& Buser, 2016) and in more theoretical discourses in sociology relating to policy and power relations, spatial dynamics and production/consumption issues of social justice, economic inequalities, discrimination and the unevenness of nutritional health (Gatrell, et al., 2011; MacKendrick, 2014; Panelli \& Tipa, 2009). Although 'foodscape' is not a term commonly used in landscape studies' literature, growing evidence from the foodscape literature reflects the impacts of food security, work and leisure patterns, lifestyle choices, taste, wellbeing and many other socio cultural influences related to food on the landscape. There is recognition of the term as 'a rhetorical device' which can communicate concepts relating to the 'distribution, impact and relationships between food and people in specific places' (Panelli \& Tipa, 2009 p.456).

Recent research suggests the active engagement, participation and agency of people in the construction of their identities, and a complex relationship between socio-psychological factors and the material landscape that creates what we understand as identities, with lifestyle as a key factor. There is much discussion about the relationship between individual and group identities. Modern urban living (including consumption patterns) in particular has created flexible or shifting identities and cultures (Gabriel \& Lang, 1995; Lang et al., 2012; Giddens, 1991). The concept of food identities can be examined in both the food and cultural studies literature. Many influential theoreticians deconstruct the relationships between people and food including those deriving inspiration from linguistics (e.g. Lévi-Strauss , 2014 [1969]; Barthes, 1975) and anthropological classifications (Douglas, 1966, 1999). Barthes suggests that an entire 'world' (social environment) is present in and signified by food; he sees it as a form of communication. Changing consumption patterns are seen to have a strong influence on urban character, both in terms of the urban dweller and the urban fabric and processes (Baudrillard, 2007; Gabriel \& Lang, 1995; Lamichane et al., 2013). Within food literatures the idea of food as central to our sense of identity or identities, in construction of a sense of place and shaping place identities has been explored in a number of ways (Caplan, 1997; Henshaw, 2014; Steel, 2009). The character of places have been found to attract people to particular parts of cities (Martens \& Warde, 1997) with sense of place a component in food selection process (Feagan, 
2007). Individual behaviour and choices about food may depend upon a 'personal food system' (Connors at al., 2001) and many other factors (Burgoine, 2009) which can be understood as our food identity. Food identities can therefore be defined as ways of characterising regular, or preferred, food consumption and/or production patterns based on what is eaten, where it is bought/grown and how people perceive the value and purpose of the food. In this respect we build on Salmon (2012) who suggests that 'eating is not only a political act but also a cultural act that reaffirms one's own identity and worldview' (p.8). In this paper we use this understanding and assume that people may hold more than one food identity and that there is an interactive link between food identities and urban landscape character.

\section{MATERIALS AND METHODS: EXPERIENCE THE URBAN LANDSCAPE}

In examining if particular foodscape character types can be discerned within the urban context an adapted expert Landscape Character Assessment (LCA) process was used to identify, classify and describe foodscape character types in three main stages: (i) desk study, (ii) field survey, (iii) classification and description (Tudor, 2014). LCA is a standard methodology for identifying, describing, classifying and mapping what is distinctive about landscapes (SNH, 2016). Landscape character types are generally regarded as distinct types of landscape that are relatively homogeneous in character and generic in nature; they 'may occur repeatedly in a study area, or occur in just one place' (Tudor, 2014, p.45). The importance of involving local knowledge is now recognised in recent LCA guidance (Tudor, 2014) as is the need to adapt methods in varying contexts (Fairclough \& Herring, 2016; Fairclough \& Wigley, 2006). During the process we recognised and employed our own experience and knowledge of the city in our reflections and discussions on our data and field observations. This was based on phenomenological and experiential research approaches that recognises both users and researchers as 'dwellers' in the landscape (Ingold, 2000) and the importance of landscape as both "performative sensorium and site and source of cultural meaning, and symbolism' (Wylie, 2007, p.161). During the Stage 1 desk study and discussion, we identified the indicators for the classification of potential foodscape character types. We searched for combinations of food-related elements and features that gave a distinctive character to the urban landscape where particular groups of consumers and their food identities could also be identified (Table 1). This was informed by consumer literature which provides concepts and categorisations of groups of people in relation to their 
consumer characteristics (Brynjolfsson \& Smith, 1999; Haque et al., 2006; Heslop et al., 2006) and literature working with classification of food provision (production and consumption) in the urban context (Lake et al., 2010; 2012). The focus was on the northern city centre area of Newcastle upon Tyne, UK; this provides a range of urban landscapes and food-related opportunities, was manageable in terms of accessibility and the time constraints of the project. During Stage 2 a route was identified and systematic primary surveys were carried out on foot over two days in April by two researchers. During field work, researchers discussed the perceptual and experiential aspects of the spaces. Observations were recorded on annotated maps and in field notes. Visual observation techniques were used which are recognised as important in landscape character analysis and for studies related to the accurate classification of food outlet types (Lake et al., 2012). Photos were taken to record particular characteristics of the places examined. Each identified typology was revisited once for clarification. In addition to visual character, particular attention was paid to recording the richness, nature and quality of sounds and smells of the spaces particularly related to food, but more generally based on understandings found in the literature relating to 'soundscapes' and 'smellscapes' to strong associations memories, identity, enjoyment and sense of place (Botteldooren et al., 2004; Carles et al., 1999; Henshaw, 2014; Ingold, 2007; Kellman, 2010; Lim, 2014; Pijanowski et al., 2011; Pistrick \& Isnard, 2013; Porteous, 1985; Southworth, 1969; Viollon \& Lavandier, 2002). In Stage 3 we revisited relevant literature to build up the picture of use and key issues; we refined the final description of the foodscape character types identified in the case study area through further analysis and discussion.

\section{INSERT TABLE 1}

\section{FINDINGS, ANALYSIS AND REVIEW: A TYPOLOGY OF URBAN FOODSCAPE CHARACTER}

The population of the city of Newcastle is characterised by a complex combination of urban poverty and a consistently high level of disposable income, coupled with a large number of young people attending the city's two universities. The population is nearly 300,000 and figures for 2009 indicate that $88 \%$ of Newcastle's population is white British and 12\% comprises other ethnic groups (Newcastle City Council, 2014a). The local economy, once primarily based on industry, now relies on the service sector, leisure and 
catering (Bailey, et al., 2004). Key underlying influences are the geographical location, the important river crossing, and the deep valley landform. There are many indicators as to the city's historic relationship with food, such as in street names, in spatial character and traditions represented in stories, songs and paintings. The Northern part of the city which constituted our study area is characterised by a range of urban landscapes, including the city centre, nearby residential areas and an important small river valley (Ouseburn corridor) containing a number of public open spaces.

We quickly realised that in a city like Newcastle, foodscape character types are likely to be continually changing and hybridizing. In the following analysis we identify seven possible urban foodscape character types (Table 2) from the rich examples provided by the Newcastle case study and discuss their characteristics and the key issues that emerged.

\section{INSERT TABLE 2}

\section{Foodscape character type 1: The landscape of the fast food takeaway}

In the predominantly residential Heaton district, the Chillingham Road is an example of an area where there has been an explosion in fast food takeaways as experienced in many cities in the UK. This area has a high student population. Some of these outlets are also cafes, but primarily it is the off-the-premises trade that is the main business, offering everything from fish and chips, to Italian pizzas, Middle Eastern doner kebabs, Chinese five-spice and Indian or Bangladeshi curries (Figure1). While the raw ingredients are grown, slaughtered and purchased at considerable distances away, the smells and debris of the food are evident. The air here is filled with the aromas of dough and spices. The detritus of the fast food industry - paper, boxes, plastic containers and waste food collects in municipal planting or blows around the streets. In this respect, the landscape is littered not with the debris of production, as in 17 th century cities, but with the debris of consumption. There is now significant evidence of the role of noise and litter in conditioning perceptions of the environment, safety and wellbeing (Clark et al., 2006; Evans et al., 2003; Hoehner et al., 2005; WendelVos et al., 2007).

\section{INSERT FIGURE 1}


Although the consumption of already prepared or fast food has a long history linked primarily to urbanisation and traceable from at least the Roman period, including for example street sellers in medieval markets (Lang et al., 2012), the increasing consumption of fast foods has been brought about by a complex combination of socio-cultural and economic factors. These include conflicting demands of time, the deskilling of people in terms of their culinary knowledge and ability, a change of eating patterns to 'grazing' of already prepared foods (Caplan, 1997), changes in technology, policy and food industries, genetic predisposition for obesity combined with certain culturally induced food habits and a massive increase in readily available, cheap food provided by international fast food chains. While the Heaton observational study suggests that such areas provide a different socialisation rather than the 'desocialisation' of food and meal patterns and culture identified by Caplan (1997), this 'grab-it-and-run' culture has an important potential impact on local residents, such as the frequent customer or delivery cars which pull up and leave often late into the night, and the chattering of late night revellers stopping off the buy food on the way home, which contribute to the perceptions of place and the cacophony of the urban night-time soundscape.

\section{Foodscape character type 2: The landscape of ethnic and 'exotic' food restaurants and shops}

Newcastle's Chinatown is located in the city centre adjacent to the ancient city walls and the remains of the Blackfriars monastery built in 1239. Although this Chinatown is based on one main street, Stowell Street, the clustering of food outlets and a slow spread of Chinese businesses to surrounding areas has meant that the area is perceived in terms of the predominant country of origin. Few ethnic food cultures have had such an impact on the landscape of UK cities as that of the Chinese, particularly in London, Manchester, Birmingham, Liverpool and Newcastle. The earliest Chinatown in Europe is in Liverpool, established in the early 19th century. Between 1950 and 1970 Chinatowns developed in the UK as a result of post-colonial immigration, primarily from Hong Kong and then further migration after the 1980s (Christiansen 2003). All these areas exhibit cultural symbols within the streetscape similar to those found on Stowell Street, Newcastle. At the North entrance to the street, there is a large Chinese style gateway, or paifang, built in 2005. This provides a clear symbol and helps to emphasise the cultural identity of this area. The street is adorned with lights and lanterns, bright red paint and gilding which symbolise joy, celebration and happiness and which mask the heterogeneous and undistinguished architecture of the street (Figure 2). At 
1 night-time the experience of the street is transformed to something exotic as a result of these elements, the views into the restaurants and the smell of food. 
INSERT FIGURE 2

\section{Foodscape character 3: Farmer's markets, places for buyers of local and artisan foods}

Newcastle Farmers' and Country Market is located in the public space around Grey's Monument, traditionally regarded as the centre of the city where key routes meet in the heart of the pedestrianised main shopping area (Figure 3). A 'Farmers Market' is one at where locally produced food is sold directly to the public (Holloway \& Kneafsey, 2000). This market occurs on the first Friday of the month throughout the year. This is in an 'upmarket' space and the market is neat, organised and calm encouraging people to dwell there rather than pass through. It captures something of the identity and liveliness of the traditional open market which has largely been lost in UK cities. Markets of all sorts transform the character of city spaces and have been shown to be significant in economic terms and social memory (Blythman, 2012; Steel, 2009). As in Newcastle, Farmers' markets in the UK occupy a variety of available publicly accessible spaces, which may or may not have or have had a particular connection with food. The stalls, tables and baskets temporarily obscure the often sterile and formalised public domain of the contemporary city centre by bringing a connection to the rural origins of food for city dwellers through the colours, textures and smells of food and their associations (Alkon, 2008). Market-holders in Newcastle, willing to engage in conversations about the food and its origins, emphasise the health and associative aspects of their products. Such markets provide alternatives to mass produced food, mainstream retailers and food that travels many food miles (GrowNYC, 2015; Petrini \& McCuaig, 2001; Kemp et al., 2010; Lang et al., 2012; Pietrykowski 2004).

\section{INSERT FIGURE 3}

\section{Foodscape character type 4: Small scale grow-your-own landscapes}

In Newcastle there is a range of examples of grow your own/small scale urban agriculture projects, the landscapes of which reflect the identity of the neighbourhood communities within which they are set (Fryer \& Rigby, 1992). Allotment sites are particularly important. Over 30,000 allotments are identified in 62 sites across the city (Newcastle City Council, 2014b) and there is significant and growing demand for 
sites (Entec, 2011). Some of these sites were established as part of the 'Dig for Victory' campaign in the 1940s (Ferres \& Townshend, 2012). The Stotes Hall Allotment Society Gardens (SHAGS) (allotments) are situated in our study area. These are on the edge of the slopes of Jesmond Dene park in the Ouseburn corridor. Jesmond is a middle-class residential area. The allotments here are strictly regulated based on the Conservation Area status and on organic growing rules; the rich soil is highly productive. The landscape character is of a traditional allotment type, but with a higher than usual density of trees, no structures such as sheds or greenhouses with a large informal community space. This is small-scale agroforestry-type character (Figure 4). The landform and its strong vegetation structure means this place is often filled with birdsong, is sunny, sheltered and tranquil with limited views out.

\section{INSERT FIGURE 4}

\section{Foodscape character type 5: The industrialised supermarket landscape}

The supermarket landscape type can be found in a number of areas in our study site. The particular place we examined was in High Heaton, a residential area where the supermarket landscape is generally characterised by mediocre building design, lack of consideration to landscape context and layout and the creation of a 'wasteland' of tarmac dominated by the demands of vehicle access (Figure 5). Since the late 1990s all night opening has been a feature of many supermarkets such as this where there is noise and light pollution as cars and late night shoppers come and go. This is an example of a general pattern of larger supermarkets located on the urban periphery, often with associated petrol stations and within the landscapes identified as 'edge lands' (Gallent \& Anderson, 2007). The character and functioning of these spaces are much criticised (Jenkins, 2014; Jiménez-Domínguez, 2014; Procter, 2012; Seely 2012; Steel, 2009). Although supermarkets in the UK have diversified their provision of services over time within the internal spaces, and there are examples of changing cultural practices, arts-based installations and events within supermarkets, the external landscape character has been little affected by such change. The new breed of smaller neighbourhood 'convenience stores' (small supermarkets) are more often embedded within the streetscape without large car-parking areas. This whole area of business is in a state of flux with a move towards on-line shopping and new store formats (Blythman, 2012; RTT, 2015) (Figure 6). 


\section{INSERT FIGURE 5 \& 6}

\section{Foodscape character type 6: Social dining, bar and café-culture landscapes}

Osborne Road, Jesmond has been transformed over the last ten years from a relatively quiet, residential neighbourhood into a linear series of eating and drinking 'destinations'. Larger dwelling houses and other buildings have been converted into bars and restaurants; often with a corresponding change in facades to represent their new uses and to attract customers. In summer this creates a lively café-culture dominated by the busy road and the views of al fresco socialising. In the evenings twinkling, party 'palaces' filled with chattering groups of people spill onto the road from terraces sheltered from the northern climate by umbrellas and external propane patio heaters (Figure 7). There are 14 bars/restaurants in 0.4 miles $(0.64 \mathrm{~km})$ with party lights in the trees, plastic hedges and artificial turf.

Eating out with friends and family in the presence of strangers is a habit that is now the norm for much of the population of the UK (Martens \& Warde, 1997). The Horizons' report of a survey, conducted online by the market research firm YouGov amongst 2,366 UK respondents, revealed that the number of survey respondents reporting eating out in the previous two weeks rose from $67 \%$ in June 2013 to $71 \%$ in July 2014 (Horizons, 2014). Catering, restaurants and hospitality have formed a major part of the restructured economies in many deindustrialised cities like Newcastle and have had a significant impact on a change in urban character as here in Jesmond. Although cafes and restaurants are spread throughout the city, there are also clear clusters, a number of which are linked to areas of urban regeneration, such as here on Osborne Road.

\section{INSERT FIGURE 7}

\section{Foodscape character type 7: The landscape of the urban food forager}

Many different kinds of urban landscapes have potential for foraging including urban amenity woodlands, parks, abandoned and brownfield land, river corridors and coastal zones. Jesmond Dene Park is part of a larger river corridor landscape with a variety of foraging opportunities (Figure 8). Evidence for foraging in the park was found through the 'Mushroom Blog' created by a group of young foragers (http://www.themushroomlog.co.uk/about/) which details a three year survey of fungi. Evidence of food 
foraging in the urban landscape is primarily through the grey literature, blogs, websites and apps, and a growing academic literature examining wild food and foraging in history and present day behaviour. Much of this is focused on gourmet cooking. In the past there have been organised foraging activities in Jesmond Dene through the ranger service and with chefs as part of the Eat! Festival 2008, and it is likely that more informal, undocumented gathering takes place. In Newcastle generally there is little published research or evidence of foraging activity except in the community woodland areas and city farms around the urban fringe (Anfield, 2008; Hall, 2014; Newcastle Gateshead Initiative, n.d.) where urban foraging is motivated by an interest in or need for food plus often a naturalist type educational study of wild plants, wild medicines and herbs and animals, and in taking part in leisure activities such as foraging courses. It is clearly seen as a lifestyle choice to take part in such activities.

\section{INSERT FIGURE 8}

\section{DISCUSSION AND RECOMMENDATIONS}

Our study suggests that landscape character relating to food in urban areas is one where there is considerable potential for investigation. A number of existing studies based on the concept of foodscapes indicate the need for a multidimensional and multi-disciplinary view that includes the analysis of perceptions and the dynamic context of food production and consumption (Bridle-Fizpatrick 2015; Burgoine et al, 2009; Panelli \& Tipa, 2009). Our study suggests that urban foodscape character types may be helpful in understanding the complex interactions between people, food and space and in revealing that people's various food identities and lifestyles can be considered in relation to the character of urban places. As food identities change over time relating to various drivers, so do the characteristics of spaces. Defining these could help our understanding of how people relate to urban food spaces in the city and in thinking about the way the dynamics inherent in foodscape character could provide opportunities for policy-makers, planners, urban designers and landscape architects in thinking about regeneration, lifestyle change and business opportunities. The context for food choices are understood to influence decisions, behaviour and food preferences, and it is increasingly recognised that perceptions of place and the design of food outlets have an important effect on these choices (Bridle-Fitzpatrick, 2015). 
This study recognises the increasing importance to people of the productive capacity of the city; the links between people's desire to grow and gather food in urban areas could be a useful basis for developing more sustainable urban lifestyles and energy recycling systems as proposed in Odum's (1975 [1963]) classic study. There is evidence of a long and continuous history of keeping animals, cultivating small plots and use of animal and human wastes for food production within urban areas in many countries (Gordon, 1990). Only a traditional allotment type was identified in terms of food growing in our study area. However food is grown in urban areas in many different places and ways (Viljoen et al., 2005) for many different reasons (Colasanti et al., 2012; Crouch \& Ward, 1994; Levin et al., 2000; Sandover, 2013) which may be linked to other food initiatives and social aims such as skills development, particularly in relation to youth and voluntary cultures. Urban food growing and foraging activities are also reported as having a significant role in periods of severe economic and environmental crises (McLain et al., 2014; Poe et al., 2014; Vitello \& Brinkley, 2014). There is a growing body of work examining the legal, political and ecological issues which may restrict foraging in urban public spaces or see foraging as subversive practice that affects the urban landscape character and biodiversiy (Tornaghi, 2014). However these issues were not discernible in our case study area through the methods used. While foraging was indicated through the desk study and local knowledge, the identification of this foodscape type was weak and needs different data gathering methods to determine the extent of this type of interaction with the urban landscape in Newcastle.

Our examination suggests that food identities in the city are fluid, dependent on the interactions between social change, class, values, activities, desires, association, lifestyle trends and behaviour. Foodscape character types in cities are primarily determined by consumers, however new potential types appear to be opening up, where producer and consumer categories blur. Thus there may be identifiable hybrid types and types emerging as a result of alternative and disruptive food practices, changing access and the emergence of new public spaces, particularly in areas not traditionally related to food systems. These include pop-up cafés and other colonisations and temporary use of spaces, kiosks, roof and container gardens, walls and 'guerrilla gardening' activities such as the planting of fruit trees on public land. There are many areas of a city like Newcastle where new foodscape character types may not be obvious without a broader study over a longer period of time, particularly those where people's food identities are more ephemeral or have less immediately obvious impact on the character of the physical fabric of spaces. 


\section{INSERT FIGURE 10}

In Hauck-Lawson and Dutsch's (2008) book 'Gastropolis' the city of New York is presented as a 'culinary smorgasbord' reflecting the city's cultural makeup and heritage. Steel's (2009) Hungry City suggests that food shapes cities and by doing so moulds the behaviour of city dwellers. These and many other books indicate the strength of feeling and connection that people have between place and food traditions. In all cities the examination of the role of food provides a rich source of stories with many possible interpretations.

Phenomenological theory suggests that people are active participants in the creation of landscape (Wylie, 2007) and its character in which case we suggest that people's food identities have an impact upon the character of the landscape and landscape character types are discernible. As new relationships (identities) with food emerge, these both condition, and are conditioned by the processes of the urban landscape and new urban landscape character types evolve. All stages of the production, distributions, marketing, consuming and the post-consumption processes are dynamic and shape the identity of places as well as shape and respond to the behaviour of the users. Some past interactions leave discernible traces in the urban fabric in the form of physical features, but also as more intangible memories and associations, place names and other characteristics that characterisation methods can help to capture. Our emphasis on the use of sensory perceptions emerges from the importance of senses in perceptions of food and therefore in capturing the associations and meanings which contribute to the urban foodscape type classification.

This study suggests that the basic premise of foodscape character analysis is one that can be used in addition to existing understandings of foodscapes to compile baseline information that can be used to guide landscape change in the same way as LCA methods are used in other contexts in the UK. While further research based on empirical work to test this concept would be useful, we believe that this paper demonstrates that foodscape character types are a way of understanding the character of changing city landscapes (in spatial, functional and associative ways) and something of the complexity of relationships that people have with food and landscapes that is often poorly researched or conflictual.

The emergence of an increasing academic literature and popular culture concerning people's 
interactions with food and multidisciplinary explorations of the understanding of foodscapes has provided the opportunity to consider urban landscapes through a previously unexplored lens based on landscape character analysis. Although we recognise this is a small exploratory study, we believe there is considerable potential for this approach to help provide a more holistic understanding of the complex role food plays in people's lives as well as in the construction of character within cities.

We believe that the concept of foodscape character provides a way of looking at urban landscapes that could be used as a planning tool that would not only provide a framework for understanding history and change, but is primarily about understanding and identifying present relationships between people, food and places in the city.

\section{REFERENCES}

Alkon, A. (2008). Paradise or pavement: the social constructions of the environment in two urban farmers' markets and their implications for environmental justice and sustainability. Local Environment, 13(3), 271-289.

Anfield, T. Foraging for food, BBC Tyne Report 08.05.2008. Retrieved from http://www.bbc.co.uk/tyne/content/articles/2008/05/08/trai_anfield_foraging_feature.shtml [accessed 11.03.15]

Bailey, C. Miles, S. \& Stark, P. (2004). Culture-led urban regeneration and the revitalisation of identities in Newcastle, Gateshead and the North East of England. International Journal of

Cultural Policy, 10(1), 4765.

Barthes, R. (1975). Toward a psychosociology of contemporary food consumption in Forster, E. and Forster, R. (eds) European diet from preindustrial to modern times. (pp. 47-59). New York: Harper \& Row.

Baudrillard, J. (2007). The Consumer Society. London: Sage.

Blythman, J. (2012). Has the UK fallen out of love with the supermarket? Open Learn/Open University. Retrieved from http://www.open.edu/openlearn/society/politicspolicypeople/sociology/hastheukfallenoutlovethesupermarket [accessed 06.03.15]. 
Botteldooren, D., Coensel, B. \& De Meur, T. (2004). The temporal structure of the urban soundscape, Journal of Sound and Vibration, 292(1-2), 105-123.

Bridle-Fitzpatrick, S. (2015). Food deserts or food swamps? A mixed-methods study of local food environments in Mexican city. Social Science \& Medicine, 142, 202-213.

Brynjolfsson, E \& Michael D. Smith (1999). Frictionless Commerce? A Comparison of Internet and Conventional Retailers. Management Science, 46 (4), 563-585.

Burgoine T., Lake, A.A., Stamp, E., Alvanides, S., Mathers, J.C., \& Adamson, A.J. (2009). Changing foodscapes 1980-2000, using the ASH30 Study. Appetite, 53, 157-165 doi: 10.1016/j-appet.2009.05.012 Caplan, P. (1997). Approaches to the study of food, health and identity, in: Caplan, P. (ed) Food, Health and Identity. (pp. 1-31). London: Routledge

Carles, J.L., Barrio, I.L. \& de Lucio, J.V. (1999). Sound influence on landscape values. Landscape \& Urban Planning, 43,191-200.

Christiansen, F. (2003). Chinatown, Europe: An Exploration of Overseas Chinese Identity in the 1990s. London: Routledge/Curzon.

Clark, C., Stansfeld, S.A. \& Candy, B. (2006). A systematic review on the effect of the physical environment on mental health. Epidemiology, 17(6), S527.

Colasanti, K. J., Hamm, M. W. \& Litjens, C. M. (2012). The City as an 'Agricultural Powerhouse'? Perspectives on Expanding Urban Agriculture from Detroit, Michigan. Urban Geography, 33(3), 348-369. Connors, M., Bisogni, C.A., Sobal, J. \& Devine, C.M., (2001). Managing values in personal food systems. Appetite, 36, 189-200 doi: 10.1006/appe.2001.0400.

Crouch, D. \& Ward, C. (1994). The Allotment: Its Landscape and Culture. Nottingham: Mushroom. Douglas, M. (1966). Purity and Danger: An analysis of concept of pollution and taboo. London: Routledge.

Douglas, M. (1999). Implicit Meanings: Selected Essays in Anthropology. London: Routledge. $2^{\text {nd }}$ edn. Entec (2011). Green Infrastructure Evidence Base. Final Report for Newcastle City Council and Gateshead Council by Entec UK Ltd., Newcastle upon Tyne, UK. 
Evans, G. W., Wells, N. M. \& Moch, A. (2003). Housing and mental health: A review of the evidence and a methodological and conceptual critique. Journal of Social Issues, 59(3), 475-500.

Fairclough, G.J. \& Wigley, A. (2006). Historic Landscape Characterisation: An English approach to landscape understanding and the management of change, in del Arbo, M.R. \& Orejas, A. (eds) Landscapes as Cultural Heritage in the European Reseach. Proceedings of COST A27 Workshop, Madrid 2004, pp.87106.

Fairclough, G. \& Herring, P. (2016). Lens, mirror, window: interactions between Historic Landscape Characterisation and Landscape Character Assessment, Landscape Research doi: $10.1080 / 01426397.2015 .1135318$.

Feagan, R. (2007). The place of food: mapping out the 'local' in local food systems. Progress in Human Geography 31(1), 23-42.

Ferres, M. \& Townshend, T.G. (2012). The social, health and wellbeing benefits of allotments: Five societies in Newcastle, GURU Working Paper No. 47. Newcastle upon Tyne: Newcastle University. Fryer, P. \& Rigby, G. (1992). Peaceable Kingdoms: Allotment Gardens in Newcastle upon Tyne. Newcastle: Newcastle upon Tyne Leisure Services.

Gabriel, Y. \& Lang, T. (1995). The Unmanageable Consumer: Contemporary Consumption and its Fragmentations. London: Sage.

Gallent, N. \& Anderson, J. (2007). Representing England's rural-urban fringe. Landscape Research, 32(1), 122.

Gatrell, J.D, Reid, N. \& Ross, P. (2011). Local food systems, deserts, and maps: The spatial dynamics and policy implications of food geography. Applied Geography, 31, 1195-1196 doi:

10.1016/japgeog.2011.01.013

Giddens, A. (1991). Modernity and Self-Identity. Cambridge: Polity Press.

Goodman, M.H.K., Maye, D., \& Holloway, L. (2010). Ethical Foodscapes? Premises, Promises and Possibilities. Environment Politics and Development Working Paper Series. Department of Geography, Kings College London. Paper No. 29.

Gordon, D. (ed) (1990). Green Cities: Ecologically sound approaches to urban space. Montreal:

Black Rose Books. 
GrowNYC (2015). Greenmarket Farmers Markets website. Retrieved from

http://www.grownyc.org/greenmarket [accessed 04.03.15].

Hall, J. (2014). It's time to EAT! out as acclaimed food festival returns. The Journal. 8 August 2014 (Eat festival). Retrieved from http://www.thejournal.co.uk/culture/fooddrinknews/itstimeeatoutacclaimed7578196 [accessed 11.03.15].

Haque, A., Sadeghzadeh, J. \& Khatibi, A. (2006). Identifying Potentiality Online Sales in Malaysia: A Study On Customer Relationships Online Shopping. Journal of Applied Business Research, 22(4), 119130.

Hauck-Lawson, A. \& Deutsch, J. (2010). Gastropolis: Food and New York City. New York: Columbia University Press.

Henshaw, V. (2014). Urban Smellscapes: Understanding and designing city smell environments London: Routledge.

Heslop, L., Madill, J., Duxbury, L. \& Dowdles, M. (2006). How Single and Married Women Organize to Get the Food on the Table Every Day: Strategies, Orientations, Outcomes and the Role of Convenience Foods. Advances in Consumer Research, 33, 599-605.

Hoehner, C.M., Brennan Ramirez, L.K., Elliott, M.B., Handy, S.L. \& Brownson, R.C. ( 2005). Perceived and objective environmental measures and physical activity among urban adults. American Journal of Preventive Medicine, 28(1), 105-116.

Holloway, L. \& Kneafsey, M (2000). Reading the Space of the Farmers’ Market: A Preliminary Investigation from the UK. Sociologia Ruralis, 40(3), 285-299.

Horizons (2014). Britain's eating out sector sees strong recovery in the regions. Horizons Eating Outlook. Retrieved from http://www.hrzns.com/news/britainseatingoutsectorstrongrecoveryregions [accessed $06.03 .15]$

IGD (Institute of Grocery Distribution) (2015). UK Grocery Retailing 2014. Retrieved from http://www.igd.com/Research/Retail/retailoutlook/3371/UKGroceryRetailing/ [accessed 28.04.15]. Ingold, T. (2007). Against soundscape, in E. Carlyle (ed.). Autumn Leaves: Sound and the Environment in Artistic Practice. (pp. 10-13) Paris: Double Entendre.

Ingold, T. (2000). The Perception of the Environment: Essays on Livelihood, Dwelling and Skill 
(London, Routledge).

Jiménez-Domínguez, B. (2014). Urban Appropriation and Loose Spaces in the Guadalajara Cityscape. in: Franck, K. \& Stevens, Q. (eds) Loose Space: Possibility and Diversity in Urban Life. (pp.96-112). Abingdon: Routledge.

Jenkins, S. (2014). Big supermarkets may be dying but they leave a plague on the landscape. The Guardian. Thursday 20 November. Retrieved from http://www.theguardian.com/commentisfree/2014/nov/20/bigsupermarketsdyingplaguelandscaperetail [accessed 06.03.15].

Kelman, A. (2010). Rethinking the Soundscape: A Critical Genealogy of a Key Term in Sound Studies. Senses and Society, 5(2), 212-34.

Kemp, K., Insch, A., Holdsworth, D. K. \& Knight, J. G. (2010). Food miles: Do UK consumers actually care? Food Policy, 35(6), 504-513.

Kelman, A. (2010). Rethinking the Soundscape: A Critical Genealogy of a Key Term in Sound Studies. Senses and Society, 5(2), 212-234.

Lake, A.A., Burgoine, T., Greenhalgh, F., Stamp, E. \& Tyrrell, R. (2010). The foodscape: classification and field validation of secondary data sources. Health Place 16(4), 666-673. doi:

10.1016/j.healthplace.2010.02.004. Epub 2010 Feb 18.

Lake, A., Burgoine, T., Stamp, E., \& Grieve, R. (2012). The foodscape: classification and field validation of secondary data sources across urban/rural and socio-economic classifications in England. International Journal of Behavioral Nutrition and Physical Activity 9, 37 http://www.ijbnpa.org/content/9/1/37 [accessed 17.02.16].

Lamichhane, A.P.O., Warren, J., Puett, R., Porter, D.W., Bottai, M., Mayre-Davis, E.J., \& Liese, A.D., (2013). Spatial patterning of supermarkets and fast food outlets with respect to neighborhood characteristics. Health \& Place, 23, 157-164.

Lang, T., Barling, D. \& Caraher, M. (2012). Food Policy: Integrating Health, Environment \& Society. Oxford: OUP. $2^{\text {nd }}$ edn. 
Levin, C., Armar-Klemesu, M., Ruel, M., Morris, S. \& Ahiadeke, C. (2000). Urban livelihoods and food and nutrition security in Greater Accra, Ghana. Washington, DC: International Food Policy Research Institute.

Lévi-Strauss, C. (2013). The Culinary Triangle [orig. 1966], in Counihan, C. \& Van Esterik, P. (eds)

Food and Culture: A Reader. London: Routledge. $3^{\text {rd }}$ edn. pp.40-47.

Lim, C.J. (2014). Food City. Abingdon: Routledge.

MacKendrick, N. (2014). Foodscape, Contexts. Retrieved from https://contexts.org/articles/foodscape/ [accessed 19.02.2016]

McLain, R.H. Hurley, P.T., Emery, M. R. \& Poe, M. R. (2014). Gathering “wild” food in the city: rethinking the role of foraging in urban ecosystem planning and management. Local Environment, 19(2), 220-240. doi:10.1080/13549839.2013.841659

Martens, L. \& Warde, A. (1997). Urban pleasure? On the meaning of eating out in a northern city, in: Caplan, P. (ed) Food, Health and Identity. (pp.131-150). London: Routledge.

Mikkelsen, B.E. (2011). Images of foodscapes: introduction to foodscape studies and their application in the study of healthy eating out-of-home environments. Perspectives Public Health, 131(5), 209-16.

Newcastle City Council (2014a). Newcastle Intelligence Online. Retrieved from http://www.newcastle.gov.uk/yourcouncilanddemocracy/statisticsandcensusinformation/equalitystatisticsresearchandinformation\#population [accessed 14.01.2015].

Newcastle City Council (2014b). Allotments website. Retrieved from

https://www.newcastle.gov.uk/leisurelibrariesandtourism/parksandcountryside/allotments [accessed 04.03.15].

Newcastle Gateshead Initiative (n.d.). Found foraging: urban foraging, Eat Festival workshop at Rising Sun (urban fringe) farm. Retrieved from http://www.newcastlegateshead.com/whatson/foundforagingurbanforagingp751111[accessed 11.03.15].

Odum, E.P. (1975 [1963]). Ecology, the link between the Natural and the Social Sciences. London: Holt Rinehart \& Winston.

Panelli, R. \& Tipa, G. (2009). Beyond foodscapes: considering geographies of Indigenous well-being. 
Health \& Place, 15, 455-465. doi: 10.1016/j.healthplace.2008.08.005

Petrini, C. \& McCuaig, W. (2001). Slow Food: the case for taste. New York: Columbia University Press.

Pietrykowski, B. (2004). You are what you eat: the social economy of the slow food movement. Review of Social Economy, 62(3), 307-321.

Pijanowski, B.C., Villanueva-Rivera, L.J., Dumyahn, S.L., Farina, A., Krause, B., Napoletano, B.M., Gage, S.H. \& Pieretti, N. (2011). Soundscape ecology: the science of sound in the landscape. BioScience 61(3), 203-216.

Pistrick, E. \& Isnart, C. (2013). Landscapes, soundscapes, mindscapes: introduction. Etnográfica, 17(3), $503-513$

Poe, M.R., Le Compte, J, McLain, R., \& Hurley, P. (2014). Urban foraging and the relational ecologies of belonging. Social \& Cultural Geography, 159(8), 901-919. doi: 10.1080/14649365.2014.908232 Porteous, J.D. (1983). Smellscape. Progress in Physical Geography, 9(3), 356-378.

Procter, E. (2012). Sustainable transport v biodiversity and community food production: case study of a landscape dilemma. Landscapism blog posted Wednesday 4 th July at $10.26 \mathrm{pm}$.

http://landscapism.blogspot.co.uk/2012/07/sustainabletransportvbiodiversity.html [accessed 09.07.12]

RTT (The KPMG/Ipsos Retail Think Tank) (2015). The future of the grocery sector in the UK.

Retrieved from

http://www.kpmg.com/uk/en/issuesandinsights/articlespublications/newsreleases/pages/thefutureofthegrocerysectorintheuk.aspx [accessed 06.03.15].

Roe, E. \& Buser, M. (2016). Becoming ecological citizens: connecting people through performance art, food matter and practices. Cultural Geographies. doi: 10.1177/1474474015624243

Salmon, E. (2012). Eating the Landscape: American Indian Stories of Food, Identity and Resilience. Tuscon: The University of Arizona Press.

Sandover, R. (2013). Doing Food-Knowing food: An exploration of allotment practices and the production of knowledge through visceral engagement. Submitted for as a thesis for the degree of Doctor of 
Philosophy to the University of Exeter, August 2013. Retrieved from

https://ore.exeter.ac.uk/repository/handle/10871/14205 [accessed 29.02.16]

Seely, A. (2012). Supermarkets: competition enquiries into the groceries market. House of Commons Library. Retrieved from http://researchbriefings.files.parliament.uk/documents/SN03653/SN03653.pdf [accessed 02.07.2013].

SNH (Scottish Natural Heritage) (2016). Landscape Character Assessment (LCA). Retrieved from http://www.snh.gov.uk/protecting-scotlands-nature/looking-after-landscapes/lca/ [accessed 17.02.16].

Soloman, D., (2012). Urbaniahoeve: expanded urban agriculture, in Viljoen, A. \& Wiskerke, J.S.C. (eds) Sustainable food planning: evolving theory and practice. (pp. 365-392) Netherlands: Wageningen Academic.

Southworth, M. (1969). The Sonic Environment of Cities. Environment and Behaviour, 1, 49-70.

Steel, C. (2009). Hungry City: How Food Shapes Our Lives. London: Vintage.

Tornaghi, C. (2014). How to set up your own urban agricultural project with a socioenvironmental justice perspective: A guide for citizens, community groups and third sector organisations. Leeds: The University of Leeds. Retrieved from

http:/www.urbanfoodjustice.org/wpcontent/uploads/2014/04/Tornaghi_Howtosetupyourownurbanagriculturalproject_2014.pdf [accessed 11.03.15].

Tudor, C., (2014). An Approach to Landscape Character Assessment. Natural England. Retrieved from www.gov.uk/natural-england [accessed 29.02.16].

Viljoen, A., \& Wiskerke, J.S.C. (eds) (2012). Sustainable Food Planning: Evolving theory and practice. NL: Wageningen.

Viollon, S., Lavandier, C. \& Drake, C. (2002). Influence of visual setting on sound ratings in an urban environment. Applied acoustics, 63(5), 493-511.

Vitello, D. \& Brinkley, C. (2014). The Hidden History of Food System Planning. Journal of Planning History, 13(2), 911-912.

Wendel-Vos, W. M. S. J. F., Droomers, M., Kremers, S., Brug, J. \& Van Lenthe, F. (2007). Potential environmental determinants of physical activity in adults: a systematic review. Obesity reviews 8(5), 425- 
440.

Wylie, J. (2007). Landscape. Abingdon: Routledge. 


\begin{tabular}{|c|c|c|c|c|}
\hline \multirow{2}{*}{$\begin{array}{c}\text { Foodscape Character } \\
\text { Consideration }\end{array}$} & \multirow{2}{*}{$\begin{array}{c}\text { Key Characteristics, patterns, } \\
\text { elements }\end{array}$} & \multicolumn{3}{|c|}{ Classification Methods/Tools } \\
\hline & & $\begin{array}{l}\text { Desk } \\
\text { Study }\end{array}$ & $\begin{array}{c}\text { Field } \\
\text { Observation }\end{array}$ & $\begin{array}{l}\text { Researcher } \\
\text { Knowledge }\end{array}$ \\
\hline \multicolumn{5}{|l|}{$\begin{array}{l}\text { Physical Form/ } \\
\text { Morphology }\end{array}$} \\
\hline & Linearity/street pattern & $\bullet$ & $\bullet$ & $\bullet$ \\
\hline & $\begin{array}{l}\text { Enclosure/2D \& 3D form of } \\
\text { buildings }\end{array}$ & $\bullet$ & $\bullet$ & \\
\hline & $\begin{array}{l}\text { Structures (other than } \\
\text { buildings) }\end{array}$ & $\bullet$ & $\bullet$ & \\
\hline & Streetscape decoration etc. & & $\bullet$ & \\
\hline & Materials, colours \& textures & $\bullet$ & & \\
\hline & Slope/steps/levels & & $\bullet$ & \\
\hline & Street Furniture & & $\bullet$ & \\
\hline & Microclimate & & $\bullet$ & \\
\hline & $\begin{array}{l}\text { Historic development/time } \\
\text { depth }\end{array}$ & $\bullet$ & $\bullet$ & $\bullet$ \\
\hline & 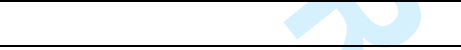 & & & \\
\hline & 00 & & & \\
\hline \multicolumn{5}{|l|}{$\begin{array}{l}\text { Cultural/Social } \\
\text { Factors \& Criteria }\end{array}$} \\
\hline & Outlet types & - & - & \\
\hline & Outlet clustering & $\bullet$ & $\bullet$ & $\bullet$ \\
\hline & Users/Consumer Group & $\bullet$ & $\bullet$ & $\bullet$ \\
\hline & Users behaviours \& activities & +2 & $\bullet$ & $\bullet$ \\
\hline & Meanings \& associations & $\bullet$ & $\bullet$ & $\bullet$ \\
\hline \multirow{2}{*}{\multicolumn{5}{|c|}{$\begin{array}{l}\text { Aesthetic/Perceptual } \\
\text { Factors \& Criteria }\end{array}$}} \\
\hline & & & & \\
\hline & Sounds (type \& quality) & & $\bullet$ & $\bullet$ \\
\hline & Smells (type and quality) & & $\bullet$ & $\bullet$ \\
\hline & Visual quality & & 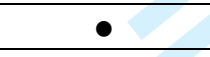 & \\
\hline & 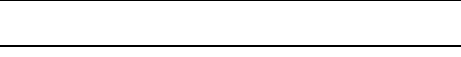 & & & \\
\hline
\end{tabular}




\begin{tabular}{|c|c|c|}
\hline $\begin{array}{l}\text { Foodscape character } \\
\text { type }\end{array}$ & $\begin{array}{l}\text { Example foodscape location } \\
\text { in Newcastle upon Tyne }\end{array}$ & Key foodscape characteristics found in case study area \\
\hline $\begin{array}{l}\text { 1. The landscape of } \\
\text { the fast food } \\
\text { takeaway }\end{array}$ & $\begin{array}{l}\text { Chillingham Road, Heaton } \\
\text { district }\end{array}$ & $\begin{array}{ll} & \text { residential (including many student's residences) } \\
\text { - } & \text { easy vehicular access/main through route } \\
\text { - } & \text { street cafés, fast-food outlets and shops } \\
\text { - } & \text { visual clutter: litter, advertising, bins } \\
\text { - } & \text { soundscape: groups including late night chattering and traffic } \\
\text { - } & \text { smellscape: mixed scents of wide variety of cooked foods }\end{array}$ \\
\hline $\begin{array}{l}\text { 2. The landscape of } \\
\text { ethnic and exotic } \\
\text { food restaurants } \\
\text { and shops }\end{array}$ & $\begin{array}{l}\text { Newcastle's Chinatown, } \\
\text { Central Newcastle }\end{array}$ & $\begin{array}{l}\text { - } \text { heterogeneous and undistinguished architecture of the street; narrow spatially; low-rise 'back' street feel } \\
\text { - } \quad \text { predominantly Chinese restaurants and supermarkets } \\
\text { - } \quad \text { cultural symbols and decorations: Chinese style gateway (paifang), lanterns, bright red paint and gilding, pictogram signage } \\
\text { - } \quad \text { evening views and glimpses into the restaurants of exotic food being prepared and eaten; morning binbags, litter and rubbish } \\
\text { - } \quad \text { soundscape: traffic and pedestrians chatting; late night laughter } \\
\text { - } \quad \text { smellscape: exotic food cooking and preparation }\end{array}$ \\
\hline $\begin{array}{l}\text { Farmer's markets, } \\
\text { places for buyers } \\
\text { of local and artisan } \\
\text { foods }\end{array}$ & $\begin{array}{l}\text { The open space around Grey's } \\
\text { Monument, city centre }\end{array}$ & $\begin{array}{l}\text { - } \quad \text { historic city centre pedestrian space with temporary market stalls } \\
\text { - feels organised and calm encouraging people to dwell and sample rather than pass through } \\
\text { - visual characteristics of the traditional open market: tables, baskets, hand-written signage and information on food sources, } \\
\text { fruit, vegetables, cheeses etc. and prepared foods } \\
\text { - } \quad \text { soundscape: generally busy with people having conversations, sampling foods, buses passing } \\
\text { - smellscape: raw and cooked food }\end{array}$ \\
\hline $\begin{array}{l}\text { 4. Small scale grow- } \\
\text { your-own } \\
\text { landscapes }\end{array}$ & $\begin{array}{l}\text { The Stotes Hall Allotment } \\
\text { Society Gardens, on the edge of } \\
\text { the slopes of Jesmond Dene } \\
\text { park, in the Ouseburn corridor. }\end{array}$ & $\begin{array}{l}\text { - } \quad \text { residential neighbourhood and adjacent city park on valley side } \\
\text { - } \quad \text { well-established traditional allotment site with vegetable plots divided by narrow grassy paths; wild areas on boundaries } \\
\text { - } \quad \text { visually, a productive landscape: agroforestry-type character, with fruit trees, vegetables and flowers, terraced and raised } \\
\text { - } \quad \text { liminting beds, beehives, some small communal open spaces } \\
\text { - } \quad \text { soundscape: birdsong, distant and muffled city traffic } \\
\text { - } \quad \text { smellscape: vegetation and plants, soil, dampness, manure and compost }\end{array}$ \\
\hline $\begin{array}{l}\text { 5. The industrialised } \\
\text { supermarket } \\
\text { landscape }\end{array}$ & High Heaton residential suburbs & $\begin{array}{l}\text { - } \quad \text { suburban periphery adjacent to important through route } \\
\text { - large supermarket building with associated petrol station; industrial character building } \\
\text { - } \quad \text { extensive tarmac car parking area with associated night-time lighting, supermarket trolley parking areas, paving, signage. } \\
\text { - } \quad \text { exposed utilitarian feel; little/no vegetation; open views to industrial units and adjacent housing } \\
\text { - } \quad \text { soundscape: vehicular traffic, trolleys and talking; night-time noise } \\
\text { - } \quad \text { smellscape: traffic }\end{array}$ \\
\hline $\begin{array}{l}\text { 6. Social dining, bar } \\
\text { and café-culture } \\
\text { landscapes }\end{array}$ & $\begin{array}{l}\text { Osborne Road, Jesmond } \\
\text { residential area }\end{array}$ & $\begin{array}{l}\text { - broad linear route within residential area lined with bars/restaurants in refurbished hotels and former houses; substantial } \\
\text { mixed brick and rendered/painted buildings } \\
\text { - } \quad \text { al fresco terrace character with party style decoration and fairy lights, plastic hedges, artificial turf; overhead plane enclosed } \\
\text { by some small trees, umbrellas and external propane patio heaters } \\
\text { - } \quad \text { seasonal and weekend day-time café culture } \\
\text { - } \quad \text { chaotic night-time atmosphere: vehicles along the road, parked cars, taxis stopping and people wandering across the road } \\
\text { - } \quad \text { soundscape: vehicles, music, chattering } \\
\text { smellscape: cooked food and alcohol; vehicles }\end{array}$ \\
\hline 7. The landscape of & Jesmond Dene Park, Ouseburn & - urban park based on river corridor with many different kinds of urban landscape (including urban amenity woodland, open \\
\hline
\end{tabular}

URL: http://mc.manuscriptcentral.com/clar Email: journal@landscaperesearch.org 


\section{Landscape Research}

Page 26 of 35

1

2 3

4 5 6 8 9

49

- a busy city park, with areas of seclusion; long-distance views from the upper valley sides and linear views along the riverside

- soundscape: running water and waterfalls, people walking and talking, dogs, children playing, birdsong, distant vehicular

\begin{tabular}{|c|c|c|}
\hline $\begin{array}{l}\text { the urban food } \\
\text { forager }\end{array}$ & Corridor, Newcastle & $\begin{array}{l}\text { mown grass, paths, brownfield land, riverside vegetation, historic built features, semi-natural habitats, scrubland, ornamental } \\
\text { shrubs and herbaceous planting) } \\
\text { - } \quad \text { wide variety of potential for foraging throughout the year including dead and rotting timber, scrubland, mature trees } \\
\text { - a busy city park, with areas of seclusion; long-distance views from the upper valley sides and linear views along the riverside } \\
\text { - soundscape: running water and waterfalls, people walking and talking, dogs, children playing, birdsong, distant vehicular } \\
\text { hum, wheel noise from cycles and buggies being pushed } \\
\text { - smellscape: vegetation, damp soil, river water }\end{array}$ \\
\hline
\end{tabular}




\section{FIGURES}

FIGURE 1 Heaton fast food landscape where there are 22 takeaway outlets along the main stretch of road $(0.4 \mathrm{miles} / 0.64 \mathrm{~km})$

FIGURE 2: The commercialised Chinese aesthetic such as that in Newcastle's China Town is still considered exotic in the British urban landscape.

FIGURE 3: Monument Farmer's Market, Central Newcastle

FIGURE 4: SHAGS next to Jesmond Dene parkland is an important part of the green infrastructure of the city.

FIGURE 5: Grocery Sales 2014 (£174.5bn) (source IGD, 2015)

FIGURE 6: Heaton Supermarket landscape, Newcastle

FIGURE 7: Social eater landscapes - Osborne Road

FIGURE 8: Foraging potential - Jesmond Dene Park, Newcastle

TABLE 1 Key Methods Used

TABLE 2 Foodscape Character Types 


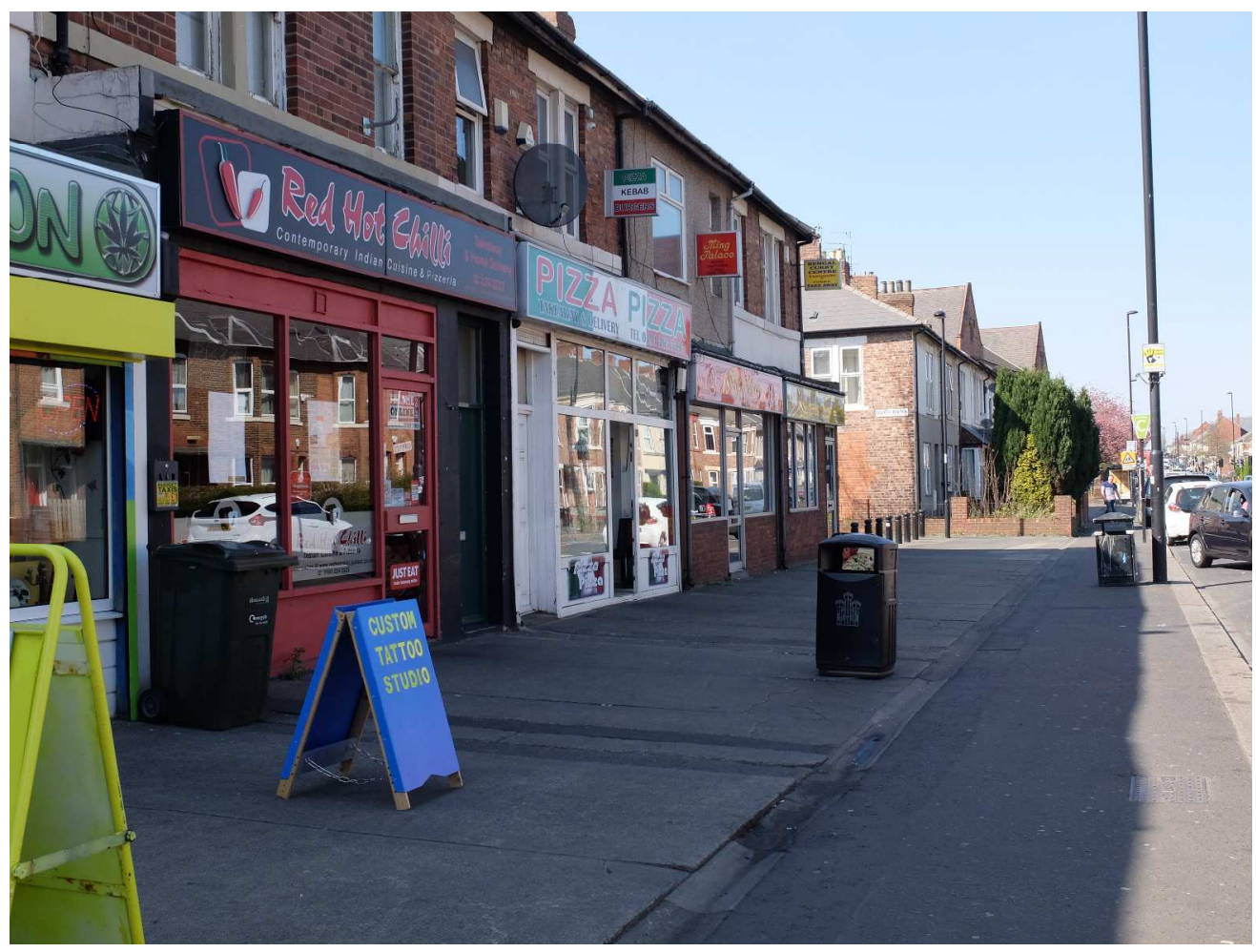

FIGURE 1 Heaton fast food landscape where there are 22 takeaway outlets along the main stretch of road $(0.4$ miles $/ 0.64 \mathrm{~km})$ Figure 1

$1411 \times 1058 \mathrm{~mm}(72 \times 72 \mathrm{DPI})$ 


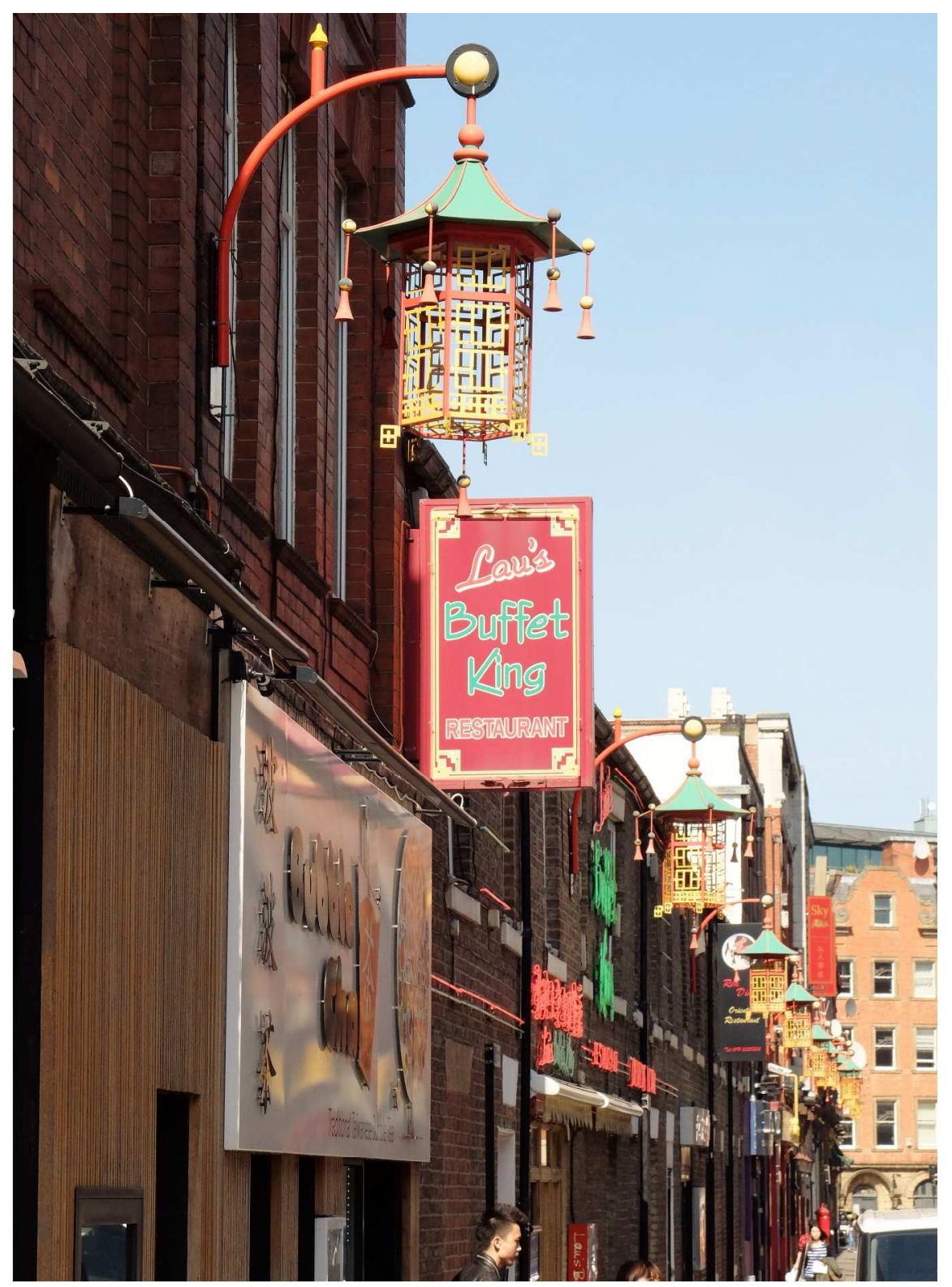

FIGURE 2: The commercialised Chinese aesthetic such as that in Newcastle's China Town is still considered exotic in the British urban landscape.

Figure 2

$996 \times 1366 \mathrm{~mm}(72 \times 72$ DPI $)$ 


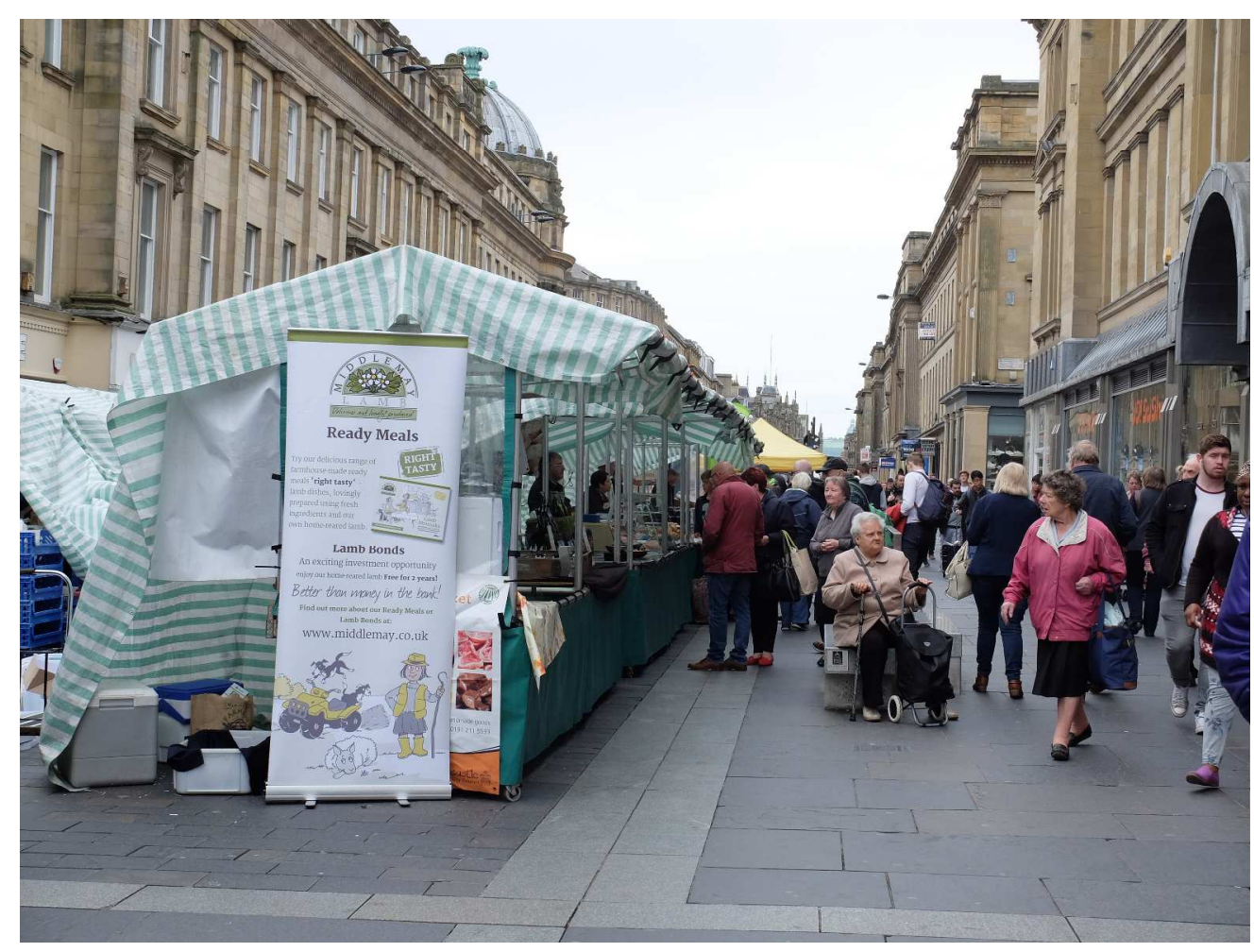

FIGURE 3: Monument Farmer's Market, Central Newcastle Figure 3

$1411 \times 1058 \mathrm{~mm}(72 \times 72 \mathrm{DPI})$ 


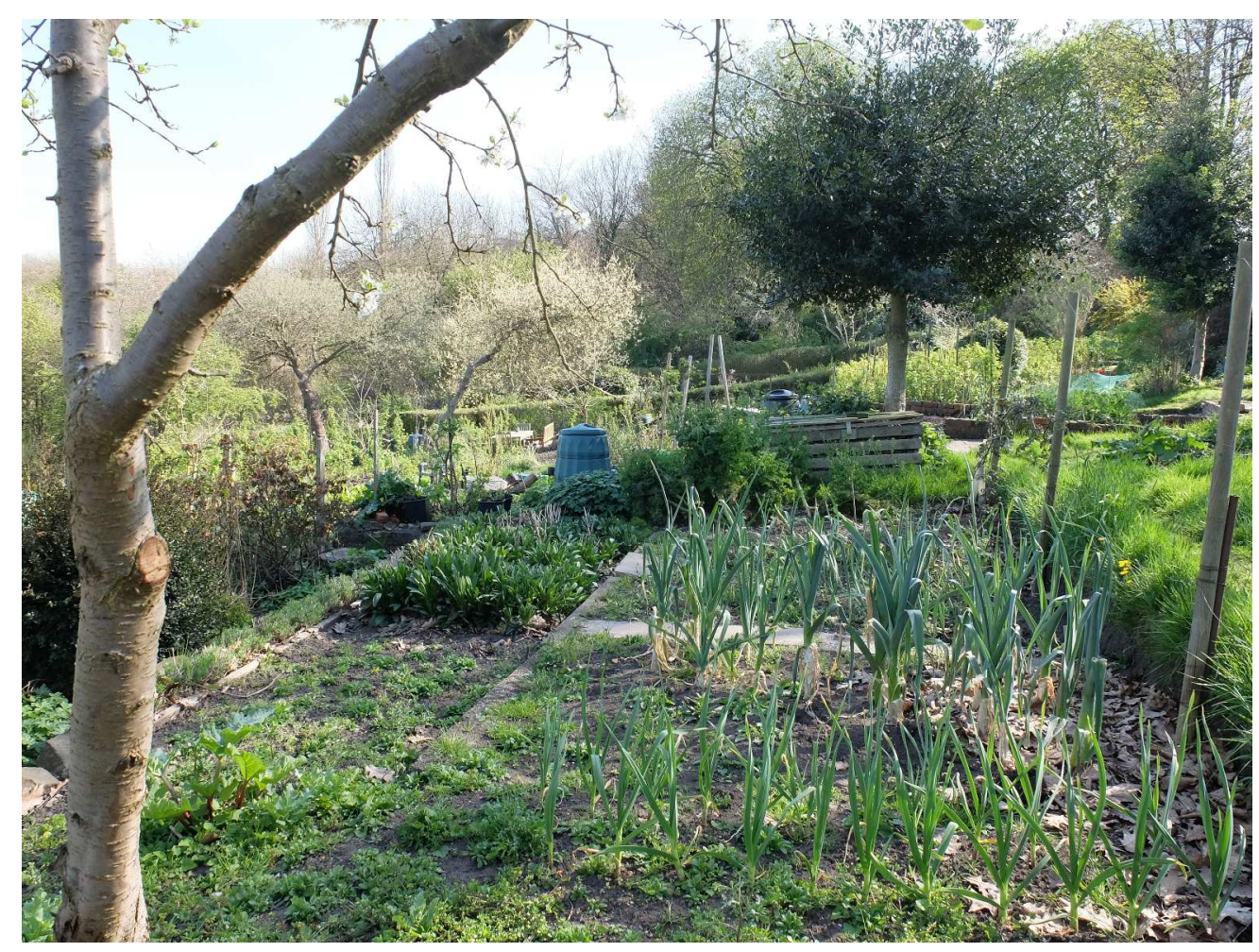

FIGURE 4: SHAGS next to Jesmond Dene parkland is an important part of the green infrastructure of the city.

Figure 4

$1411 \times 1058 \mathrm{~mm}(72 \times 72 \mathrm{DPI})$ 
Sales 2014: $£ 174.5 b n$

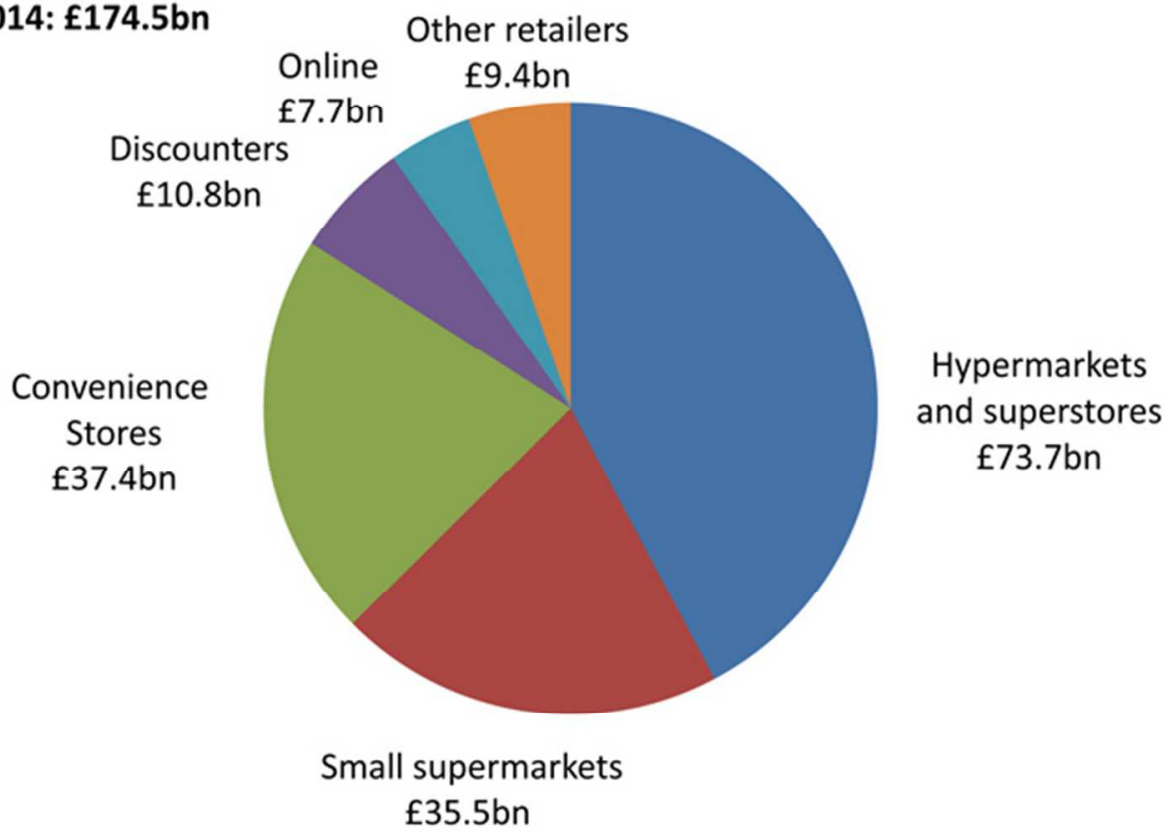

FIGURE 5: Grocery Sales 2014 (£174.5bn) (source IGD, 2015)

Figure 5 $177 \times 115 \mathrm{~mm}(100 \times 100 \mathrm{DPI})$ 


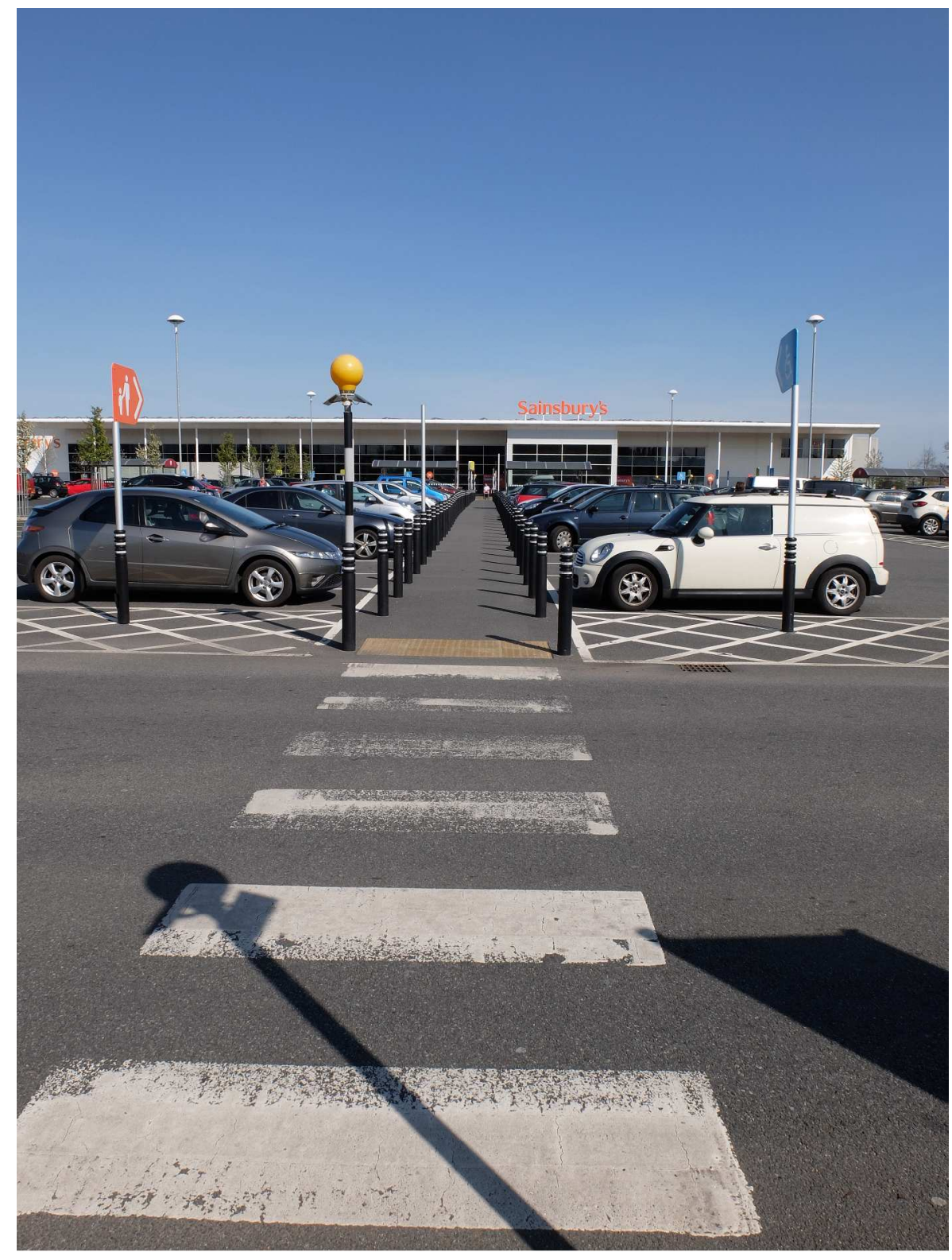

FIGURE 6: Heaton Supermarket landscape, Newcastle Figure 6 $1058 \times 1411 \mathrm{~mm}(72 \times 72 \mathrm{DPI})$ 


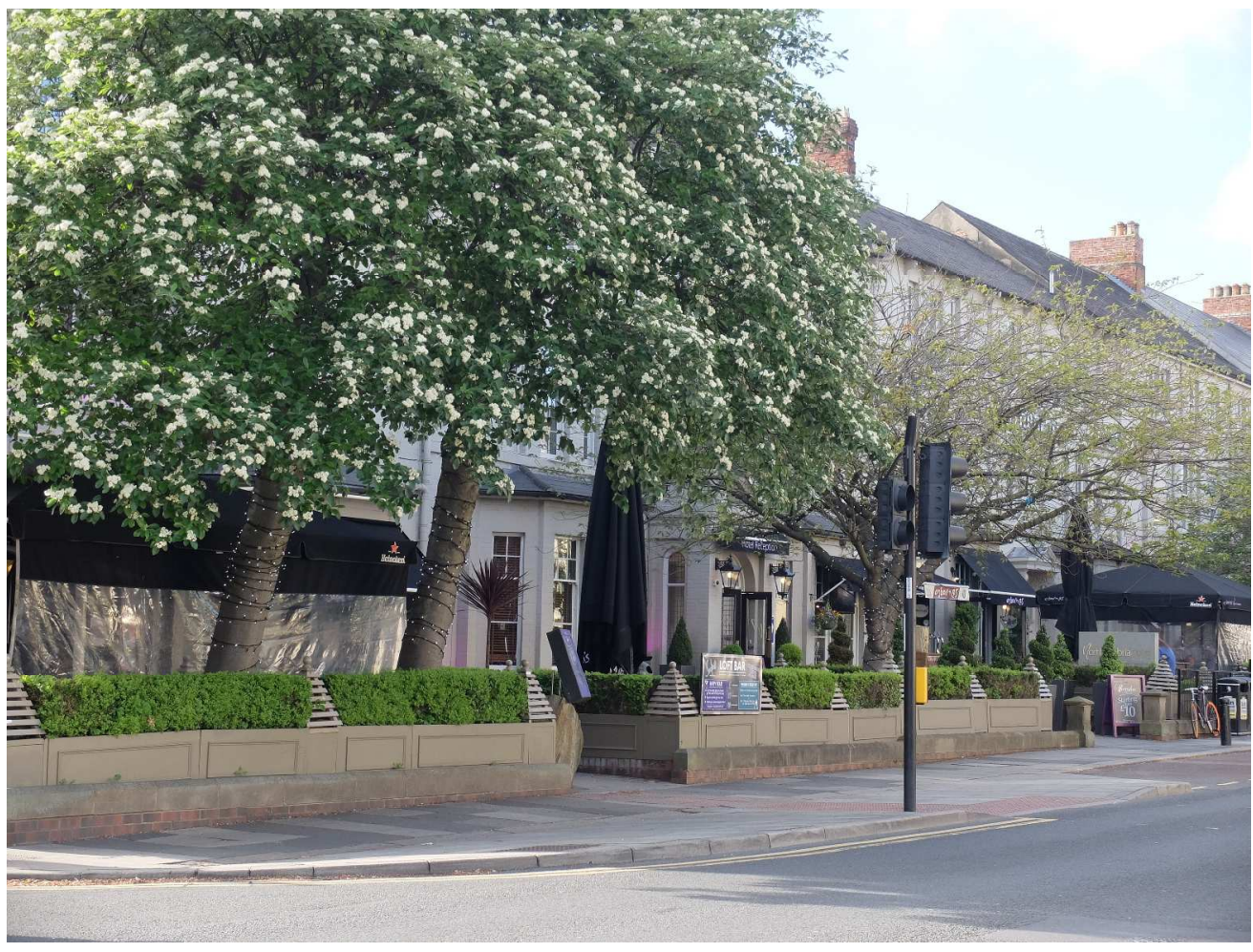

FIGURE 7: Social eater landscapes - Osborne Road

Figure 7

$1411 \times 1058 \mathrm{~mm}(72 \times 72$ DPI $)$ 


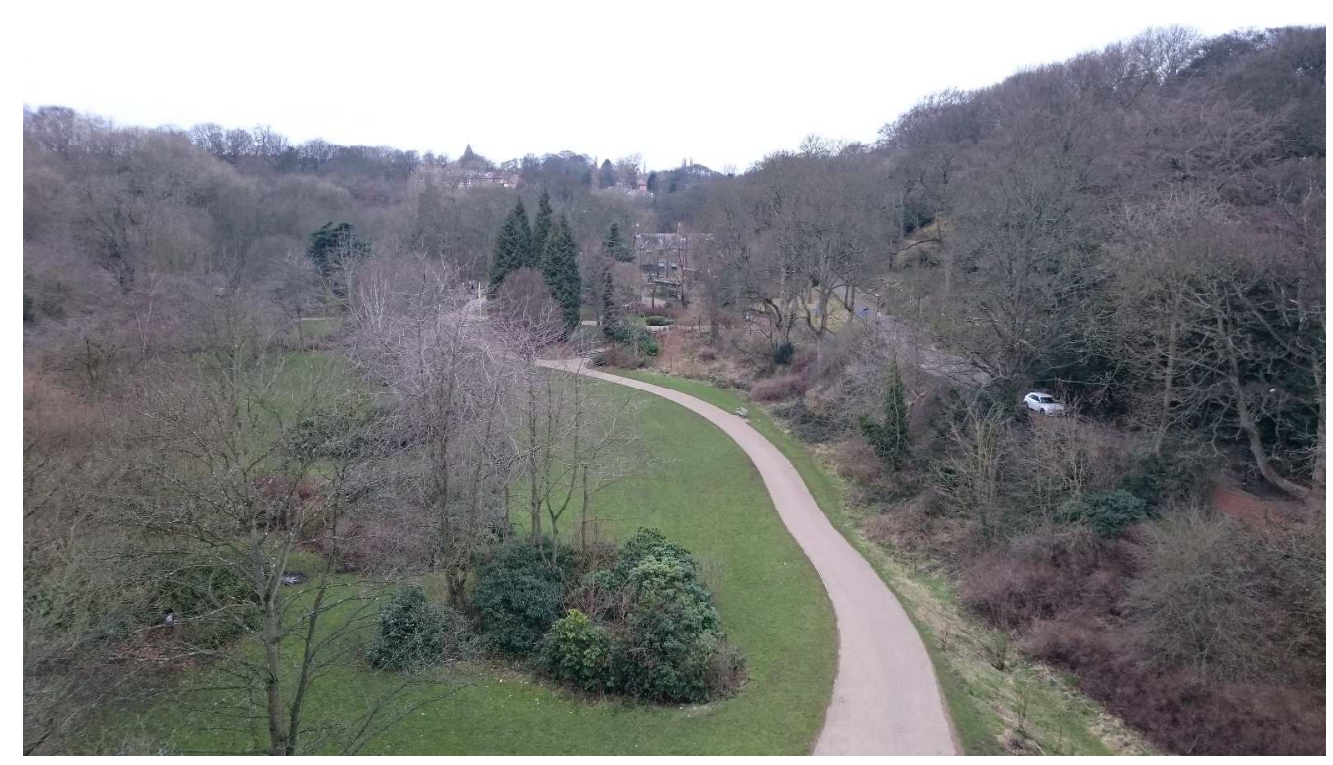

FIGURE 8: Foraging potential - Jesmond Dene Park, Newcastle Figure 8 $1354 \times 762 \mathrm{~mm}(72 \times 72$ DPI $)$ 